László ÓZSVÁRI

Gyula KASZA

Zoltán LAKNER

\title{
3.2. HISTORICAL AND ECONOMIC ASPECTS OF BIOTERRORISM
}

\section{Summary}

The use of living organisms as weapon has been seen throughout the history of mankind. In our age the growing global tension, the several malfunctional nations and the multitudinous occurrence of low-intensity conflicts increase the risk of biological terror attacks even in Europe. In case of a contingent biological terror attack the veterinarians will become key figures fighting in the forefront, because $60 \%$ of the human contagious diseases are zoonotic and the food-chain is an easily vulnerable target which is fundamentally supervised by them. Malicious, deliberate contamination of food and water supplies with different biological agents, including bacteria, viruses, parasites and bacterial toxins for terrorist purposes is a real threat to the civilian populations worldwide. Hence, in the paper the authors review the concepts, history and future trends of bio, agro and food terrorism, and the possible impacts of bioterrorism on food-chain, public health, economy and the whole society.

Keywords: bioterrorism, food chain, public health, economic impacts

\section{Introduction}

The history of mankind is about permanent conflicts that mostly ended in armed combat. The wars frequently affected the civil population as well, but since the turn of the $18^{\text {th }}$ and $19^{\text {th }}$ century the international contracts have been aiming at the isolation of the armed forces from the civil population. The international military law states that distinction should be made between the activities of armies, militias, volunteer fighting corps and the management of civil citizens in the countries at war (Kalshoven and Zegveld, 2001). After World War I the bi- and multilateral agreements restrained the use of weapons of mass destruction, above all the biological, chemical and nuclear agents. However, the implementation of these contracts has greatly weakened hence new types of conflicts have arisen since the mid- $20^{\text {th }}$ century, and the civil population from the military actions cannot be sharply separated. In these conflicts the psychological warfare (scaremongering, economic and ecological destruction, threats to the civil population, etc.) is of increasing importance. These aims can easily be achieved by biological weapons.

In the last 100 years the unconventional warfare, which is not an open war, but armed opposition, has become exceedingly dominant, especially the so-called low-intensity conflicts. These political-military oppositions between states and/or social groups have not yet reached the level of war, but have gone beyond peaceful competition. In the $21^{\text {st }}$ century the low-intensity conflicts are still prevailing. 
The use of biological weapons can be traced back to the beginning of armed combat, but they were used quite rarely in the interstate conflicts, probably because of the fear of backlash. Nevertheless, the rising global tensions, the malfunction of many states, and the spread of low-intensity conflicts can lead to the strengthening of international terrorism, and the terrorist are not abided to international laws and the concerns of the state leaders. Thus, it can be assumed that the biological agents can play a role in the hands of terrorists, and could even threaten the safety of the European countries.

\section{History}

The use of living organisms in human conflicts has been accompanying mankind throughout history. Even the early man dipped their arrows and spears into different contaminants including faeces of human or animal origin to prolong the healing process of the inflicted wounds. In the antique wars, the animal cadavers were thrown into the wells to contaminate the water supplies. In order to expel the enemies hiding in caves or taking cover bees and poisonous insects were often used (Jared, 1997).

In the medieval ages, it was a common practice to throw the corpses of animals or humans that died due to contagious diseases (mostly plague, Yersinia pestis) into the fortresses. In 1346, the tartars catapulted corpses of men deceased by the pest into the castle of Kafa on the Crimea, resulting in the Black Death plagues in Europe in the $14^{\text {th }}$ century (Varkey et al., 2002). The British army in the $17^{\text {th }}$ century distributed blankets infested with smallpox (Variola major) amongst indigenous Indians (Bronze et al., 2002). During World War I the diversionists of the German army infected the horses and cattle with glanders (Burkhordelia (Bacillus) mallei) and anthrax (Bacillus anthracis). German diversionists were also active in American and Argentine ports, and their task was to infect the animal shipments to Europe (Redmond et al. 1998).

Since its establishment the Soviet Union had been preparing for a war in which the biological agents can be used. The Russian archives are still closed, hence the soviet and post-soviet biological war preparations can primarily be known from personal reports which are often equivocal. Research and development of biological weapons started in 1926, mainly targeting the destruction of agricultural production and food supplies. According to the American intelligence service their plan was to apply the house-fly (Musca domestica) to spread the foot-and mouth-disease (Feodov, 2005).

In Japan a special military unit was founded in 1932 in order to reveal the modes of action of the biological agents. The notorius Unit 731 had conducted experiments with live humans. In the World War II Japan released bombs stuffed with fleas and flies infected with cholera onto Chinese settlements (Harris, 1992).

In World War II biological weapons were not applied, but opponents were prepared to use them. Before the war Germany began conducting experiments on the infection of agricultural fields with Colorado beetles (Epinotarsa decemlineata), but there are no data about their application (Lesho et al., 1998). During the war, the English tested anthrax-bombs on the Gruinard-islands. The experiment was so successful that the whole island was closed down for 50 years. In England large amount anthrax infected cattle feed was produced with the intention of bombing target areas, but finally this kind of actions did not take place. The United States built a plant in 1944 that could 
produce half a million anthrax bombs a month, each pieces weighing about 4 pounds. It can be assumed that due of fear of backlash these biological weapons were never applied on the battlefield (Koblenz, 2009).

After WW II the phenomenon of food terrorism appeared. In 1946 a group of avengers poisoned the bread of SS-soldiers with arsenic in a guarded camp (Khan et al., 2001). In the cold war a huge amount of biological weapons were stocked on both opponent military blocks. Its major cause was that the biological weapons had significant devastating effect that was confirmed by many experiments and estimations. Cuban references states that American secret services attempted to take agro-terror attacks against the Cuban plant production and animal husbandry at different times between 1962 and the early '90-s (Prado and Amores, 2010), but these attacks were always denied by the US government. However, it is a fact that the USA stockpiled 36 thousand kg wheat-stalk rust fungi (Puccinia graminis Pers. f. sp. tritici) in 1960. In order to disseminate this agent, a device resembling a paper aircraft was constructed, replacing the earlier technique of pathogen coated feathers (Torok et al., 1997).

In 1978 in Rhodesia (today Zimbabwe) 182 people died owing to bovine anthrax infection that was caused by governmental troops trying to weaken the economic background of the insurgents (Blancou and Pearson, 2002). According to Collins (1983) Soviet troops infected the insurgents' horses with glanders in Afghanistan so as to hamper the supply lines. Hopmann (2009) stated that since 1980s three significant biological weapon development programs have become known, of which the soviet one was the most important lasting till 1992. In 1991 after the Gulf War the production of biological weapons was proved in Iraq, so was it in South-Africa a bit later.

It is not a commonly known fact that the American army widely use biological weapons in the war on drugs. In the 1990-s in Uzbekistan a successful experiment financed by the Americans was conducted in that Fusarium oxysporum was used against growing drug plants. The results of trials, which ended in 2001, was successfully exploited in Colombia. Many scientists protested against the experiments because they were concerned about the application of this agent destroying plants without the farmers' consent (Thoumi, 2010).

We have a little knowledge about the bioterror attacks committed in the last decades. Only one action taken by a religious sect drew public attention. In 1984 an American religious sect in Oregon state, USA attacked a salad bar with Salmonella typhimurium. The attempt made 751 people contract salmonellosis (Day et al., 2011).

In 1995 the Japanese Aum Shinrikyo sect attacked the subway passengers in Tokyo with sarin gas, bringing into focus that a huge city is very unprotected against terrorist using weapons of mass destruction. The investigation revealed that the members of the sect attempted to diffuse aerosol containing anthrax and botulinum toxin at different times between 1990 and 1995. The financial power of the sect can be depicted by the facts that the total turnover of its companies was about $\$ 30$ million, and it had 5.000 members in Japan and in the states of the former Soviet Union. So it can be stated that a terrorist does not necessarily tinker with biological weapons in a primitive laboratory (Reader, 2000). 


\section{The definition of bio-, agro- and food terrorism and their impacts}

Bioterrorism is terrorism using biological weapons. Agroterrorism is bioterrorism intending the spread of diseases of plant or animal origin, resulting in fear, financial damage, and eventually instability of the society (Cupp et al., 2004). Food terrorism is bioterrorism contaminating and/or poisoning the human food and water supplies. In a wider sense it includes the attacks against food, feed and water supply chains (Wieck et al., 2007). It is of fundamental importance that bioterror attacks should not necessarily be implemented, the threat itself is adequate to cause significant damages. As the chance of the different agroterror attacks increases so do their economic effects.

\section{Bioterrorism}

The possible applications and impacts of bioterror attacks were thoroughly assessed during the cold war. Every evaluation emphasizes the significant destructive effects of the biological weapons (Table 1). In the most favourable circumstances a one-megaton hydrogen bomb would cause 570,000-1,900,000 casualties, whereas a $100 \mathrm{~kg}$ anthraxspore bomb could cause up to 1-3 million. In less optimal circumstances (windy, sunny weather) the number of casualties would still range between 130,000 and 1,400,000. The effectiveness of chemical weapons is minimal compared to that of biological weapons: $100 \mathrm{~kg}$ concentrated sarin gas, even in "optimal" case, would result in "grand total" of 8,000 casualties (U.S. Congress, 1993).

Table 1: The efficacy of application of three different mass destruction weapons

\begin{tabular}{|l|c|c|c|}
\hline $\begin{array}{c}\text { Mass destruction } \\
\text { weapon }\end{array}$ & Quantity & $\begin{array}{c}\text { Striking range } \\
\left.\mathbf{( k m}^{\mathbf{2}}\right)\end{array}$ & $\begin{array}{c}\text { Number of casualties } \\
\text { (head) }\end{array}$ \\
\hline Sarin gas & $300 \mathrm{~kg}$ & 0,22 & $60-200$ \\
\hline Bacillus anthracis & $30 \mathrm{~kg}$ & 10 & $30,000-100,000$ \\
\hline Nuclear bomb & $12,5 \mathrm{kT}$ & 7,8 & $23,000-80,000$ \\
\hline
\end{tabular}

Source: U.S. Congress 1993

According to Kaufmann et al. (1997) a Brucella melitensis aerosol attack against a town with a population of 100,000 would cause 82,500 morbidity cases and 416 mortality cases. The financial damage of this bioterror attack is estimated to be $\$ 478$ 650 million. According to the WHO (1970) estimations a $50 \mathrm{~kg}$ desiccated Brucella pathogen aerosol attack against a city of 5 million inhabitants would bring about 150,000 morbidity cases and 600 casualties. Another reason for the use of biological weapons is the low cost. In case of Francisella tularensis aerosol attack against a city, given that $5 \%$ mortality rate, would cost $\$ 2.86$ /casualty, but it would decrease to $\$$ $0.36 /$ casualty with a $40 \%$ mortality rate (Prado and Amores 2010).

The organizations for rescue services in the developed countries had been prepared for a long time to defend against the chemical attacks, but they had much less experiences as regards the biological defense, whereas this requires special knowledge and competences (Table 2.) 
Table 2: Comparison of terrorism using chemical offensive agents with that using biological war materials

\begin{tabular}{|l|l|}
\hline \multicolumn{1}{|c|}{ Chemical terrorism Impact speed } \\
\hline \multicolumn{1}{|c|}{ Beapon destruction range } \\
\hline $\begin{array}{l}\text { Fast impact - Within minutes or hours } \\
\text { after attack }\end{array}$ & $\begin{array}{l}\text { Delayed impact - Within days or weeks after } \\
\text { attack }\end{array}$ \\
\hline \multicolumn{2}{|c|}{ Involved and affected defense services } \\
\hline Areas in the wind direction & $\begin{array}{l}\text { Plant-, animal health, food safety and } \\
\text { medical officers, vets, epidemiologists, } \\
\text { microbiologists, physicians, etc. }\end{array}$ \\
\hline $\begin{array}{l}\text { Workers in the first phase of rescue } \\
\text { services (ambulance, fire service, police, } \\
\text { rescue experts, etc.) }\end{array}$ & Identification and closure of the attack site \\
\hline $\begin{array}{l}\text { Relatively well-identifiable and can be } \\
\text { cordon enclosed }\end{array}$ & $\begin{array}{l}\text { Hardly-identifiable attack site and infested } \\
\text { area, and less effective checkpoints }\end{array}$ \\
\hline \multicolumn{2}{|c|}{ Disinfection } \\
\hline Major importance & Not required in many instances \\
\hline \multicolumn{2}{|c|}{ Isolation of the affected persons } \\
\hline After disinfection usually not important & Major importance \\
\hline
\end{tabular}

Source: Own construction

\section{Agroterrorism}

The agroterror attacks against food animal populations have numerous advantages from the attackers' point of view. The most important ones are as follows:

1. Many agricultural farms have large, open pasture-lands that facilitates the easy introduction of the pathogen. The spread of loose housing systems further ease the attacks. Moreover, the agricultural companies try to make their activities more known today, thus, the agro-tourism becomes increasingly popular which further increases the chance of terror attacks (Forbord et al., 2012).

2. In the last decades a huge concentration of the food animal farms could be observed. For example, in the USA between 1965 and 2007 the number of swine farms decreased from about 1 million to 65,000, but the average herd size increased from 55 to 920 pigs. The geographical concentration of the food animal sector can easily be followed in France: in Brittany, which has about $27,000 \mathrm{~km}^{2}$ territory equalling to little bit more than $5 \%$ of the European part of France, $42.4 \%$ of the French dairy cattle, $72.1 \%$ of the French swine and $63.2 \%$ of the French waterfowl population can be found (MAPRA, 2011). The high density of the animals gives a higher chance for the contagious diseases to spread fast.

3. As a consequence of the fast development of the transportation and information systems more and more agricultural commodities and products are processed and consumed in other places than that of production. The globalisation of food production can be observed through the case of Chicken Breast A La Kiev in Dublin; the salted butter comes from Ireland, the garlic purée from China or the US or Spain, the lemon from the US, the parsley from France or the UK, the pepper from India, the chicken breast form Ireland or Belgium or the UK, the flour from Belgium or France, and the rape-oil from Australia or Hungary. It can be 
seen that the ingredients for such a simple meal stem from 10 countries (ErcseyRavasz et al., 2012). Live animals, crops, the semi- and fully processed products can all spread the pathogens of contagious diseases of plant or animal origin.

4. The trade of agricultural products and food is basically a matter of trust. Because of the complexity and public health impacts of these goods, unfavourable rumours can easily ruin their markets which were built over years or decades. For example, the BSE crisis caused $€ 92$ billion loss in the European countries which would have been equal to one-tenth of annual gross income of the cattle sector in 2003 (Cunningham, 2003).

5. It is easier to get access to the pathogens of diseases of animal or plant origin than those of human diseases. Numerous animal diseases are not zoonotic, thus, they do not pose any risks to the agents spreading the disease. Furthermore, because of the longer incubation period of certain diseases the saboteur has enough time to escape.

6. The origin of the outbreaks is often difficult to identify, so the terror attack is not necessarily revealed. The application of exotic pathogens, which are unknown on the targeted areas, can largely prolong the time of identification and the onset of the effective control of the disease. The procurement of the eligible vaccines and the set-up of the needful control measures require much more time.

\section{Food terrorism}

The studies, which were made in the last years, emphasize the global effects of the food terrorism. According to the estimations of Liu and Wein (2008), if the terrorists were able to ingest $1 \mathrm{~g}$ botulinum toxin into the milk supply system in the USA, $50,000$ gallon ( 1 standard American gallon $=3,7851)$ milk would get poisoned. In this case the number of casualties would exceed 100,000.

It is more effective for terrorists to ensure that the toxins produced by the pathogens contaminate the water supplies than the pathogens themselves. According to the WHO (1970), if the water supply system of a town with a population of 50,000 was ingested by $0.24 \mathrm{~kg}$ botulinum toxin and every inhabitant's daily water consumption was 0.51 only, the contamination would cause around $60 \%$ mortality of the population within 17.5 hours. In Hungary every official settlement (altogether 3,152) has a tap water supply system. In $95 \%$ of the Hungarian flats, that is, in more than 4.132 million flats, there is running water. The $65,978 \mathrm{~km}$ long tap water pipe system with the water reservoirs can easily be attacked (HCSO, 2012).

However, the chance of a successful terror attack against the water supply systems is greatly reduced by the regular drinking water treatments, so the purification from the biological agents might be significant. The infrastructure used for the transportation and storage of drinking water can be attacked in a more efficient way, but significant concentration of chlorine can still give sufficient protection. The ozone treatment and nanofiltration, which are more commonly used, can offset the detrimental effects of the chlorine-resistant microbes. The risk is further decreased by the fact that only $5-5.5 \%$ of the running water goes to human consumption, given that 21 per head total drinking water consumption daily, that is, $0.73 \mathrm{~m}^{3}$ yearly. Since the total annual tap water consumption in a Hungarian household is $35 \mathrm{~m}^{3}$, and the average family size is 2.51 , 
the total annual water consumption is $13.94 \mathrm{~m}^{3}$ per head (HCSO, 2012). Furthermore, between the contamination and consumption of water there is a significant time gap that further reduces the health risks of the drinking water consumption.

\section{The future development of bioterror weapons}

The more advanced biotechnology largely facilitates the invention and creation of bioterror weapons at relatively low cost. It can play a significant role in the reinforcement of pathogenicity, virulence, antibiotic resistance of the pathogens, in the enhancement of aerosol spreading of the microbes and toxins and in the construction of new and very destructive living organisms and toxins. The genetic modification can result in new mutants, which are resistant to medications, hardly identifiable, persistent and produce toxins in large amounts. Summarily, the genetic modification and other modern biotechnology procedures can create a new generation of bioterror weapons.

\section{References}

1. Blancou, J., Pearson, J.E. (2002): Bioterrorism and infectious animal diseases. „Comparative Immunology, microbiology and infectious diseases”, 26. pp. 431-443. http://dx.doi.org/10.1016/S0147-9571(03)00024-9

2. Bronze, M.S., Huycke, M.M., Machado, L.J., et al. (2002): Viral Agents as Biological Weapons and Agents of Bioterrorism. „The American Journal of the Medical Sciences”, 323. pp. 316-325. http://dx.doi.org/10.1097/00000441-200206000-00004

3. Collins, J. (1983): Soviet military perfomance in Afghanistan: a preliminary assessment. „Comparative strategy”, 14. pp. 147-168. http://dx.doi.org/10.1080/ 01495938308402661

4. Cunnigham, E.P. (2003): 'After BSE - a future for the European livestock sector', Wageningen Academic Publisher, Wageningen, p. 90. http://dx.doi.org/10.3920/978-908686-516-1

5. Cupp, O.S., Walker, D.E., Hillson, J. (2004): Agroterrorism in the US: key security challenge for the $21^{\text {st }}$ century. ,Biosecurity and bioterrorism:biodefense strategy, practice and science" 2. pp. 97-105. http://dx.doi.org/10.1089/153871304323146397

6. Day, J.B., Sharma, D., Nusrat, S. et al. (2011): Survival of Salmonella Typhi and Shigella dysenteriaein Dehydrated Infant Formula. „Journal of Food Science”, 76. pp. 324-328. http://dx.doi.org/10.1111/j.1750-3841.2011.02268.x

7. Ercsey-Ravasz, M., Toroczkay, Z., Lakner, Z., Baranyi J. (2012): 'Complexity and Vulnerability in the Human Food Web', Mühelytanulmány, Budapest.

8. Feodov, L.A. (2005): 'Szovejtszkoje biologicseszkije oruzsije, isztorija ekologija politika. Mezsdunarodnoj szocialno-ekologicseszkoj szojuz „Za himicseszkuju bezopasztnoszty’ Moszkva.

9. Forbord, M., Schermer, M., Grießmair, K. (2012): Stability and variety - products, organization and institutionalization in farm tourism. „Tourism Management”, 33. (4) pp. 895-909. http://dx.doi.org/10.1016/j.tourman.2011.08.015

10. Harris, S. (1992): Japanese Biological Warfare Research on Humans: A Case Study of Microbiology and Ethics. „Annals of the New York Academy of Sciences”, 666. pp. 21-52. http://dx.doi.org/10.1111/j.1749-6632.1992.tb38021.x

11. HCSO (2012): 'Közüzemi vezetékes ivóvízellátás' Available online: http://portal.ksh.hu/pls/ksh/docs/hun/xstadat/xstadat eves/i zrk001.html 
12. Hopmann, P.T. (2009): 'Negotiantion Risk: Controlling Biological Weapons' In: Avenhaus, R., Sjöstedt, G. (eds): 'Negotiated Risks'. Springer Verlag. Berlin-Heidelberg. http://dx.doi.org/10.1007/978-3-540-92993-2 7

13. Jared, D. (1997): 'Guns, germs and steel: the fates of Human societies'. W.W. Norton. New York. http://dx.doi.org/10.1023/A:1022157211445

14. Kalshoven, F., Zegveld, L. (2001): 'Constraints on the Waging of War. An Introduction to International Humanitarian law' International Committee of the Red Cross (ICRC), Geneva, 2001. p. 227. http://dx.doi.org/10.1017/CBO9780511995231

15. Kaufmann, A.F., Meltzer, M. I. P. (1997): The economic impact of a bioterrorist attack: are prevention and postattack intervention programs justifiable? „Emerging Infectious Diseases", 13. pp. 83-94.

16. Khan, A.S., Swerdlow, D. L., Juranek, D. D. (2001): Precautions against biological and chemical terrorism directed at food and water supplies. „Public Health reports”, 116. pp. 3-14. http://dx.doi.org/10.1093/phr/116.1.3

17. Koblenz, G. (2009): 'Living Weapons: Biological Warfare and International Security' Cornell University Press, Ithaca, NY, p. 272. http://dx.doi.org/10.3201/eid1610.100959

18. Lesho, E., Dorsey, D., Bunner, D. (1998): Feces, dead horses, and fleas. Evolution of the hostile use of biological agents. „Western Journal of Medicine”, 168. pp. 513-516.

19. Liu, Y., Wein, L. M. (2008): Mathematically Assessing the Consequences of Food Terrorism Scenarios. „Journal of Food Sciences”, 73. 346-353. http://dx.doi.org/10.1111/j.1750-3841.2008.00874.x

20. MAPRA 2011, Recensement Agricole-L'agriculture francaise en 2010-premiers résultats du recensement agricole, MAPRA, Paris.

21. Prado, E.A.S., Amores, A.,P. (2010): Historia del agroterrorismo de Estados Unidos de América contra Cuba. „Revista electrónica de Veterinaria”, 11. pp. 1-19.

22. Reader, I. (2000): 'Religous Violence in Contemporary Japan: The Case of Aum Shinrikyo' University of Hawaii Press, Honolulu. http://dx.doi.org/10.2307/3712310

23. Redmond, C., Pearce, M.J., Manchee, R.J. et al. (1998): Deadly relic of the Great war. „Nature”, 393. pp. 747-748. http://dx.doi.org/10.1038/31612

24. Thoumi, F.E. (2010): 'Competitive advantages in the production and trafficing of cocacocaine and opium-heroin in Afghanistan and the Andean countries' In: Keefer, P., Loayza, N. (eds): 'Innocent Bystanders. Developing Countries and the War on Drugs' A copublication of Palgrave Macmillan and the World Bank. Washington, DC, pp. 195-253. http://dx.doi.org/10.1596/978-0-8213-8034-5

25. Torok, T., Tauxe, R.V., Wise, R.P. (1997): A large community outbreak of Salmonella caused by intentional contamination of restaurant salad bars. "Journal of the American Medical Association", 278. pp. 389-395. http://dx.doi.org/10.1001/jama.278.5.389

26. U.S. Congress (1993): 'Proliferation of Wearpons of Mass Destruction: Asessing the Risks' U.S. Government Printing Office. Washington, D.C.

27. Varkey, P., Poland, G.A., Cockrill, F.R., et al. (2002): Confronting bioterrorism: physicians on the front line. „Mayo Clinic Proceedings" 77. pp. 661-672. http://dx.doi.org/10.4065/77.7.661

28. WHO (1970): 'Health aspects of chemical and biological weapons' WHO, Geneva.

29. Wieck, C., Rudloff, B., Wahl, T. (2007): The bioterrorism act of the USA and international food trade: evaluation WTO conformity and effects of bilateral import. „Agrarwirtschaft”, 56. pp. 147-160. 